https://doi.org/10.18778/7525-913-1.15

WOJCIECH ŚWITALSKI*

\title{
Edukacyjna funkcja czasopism brydżowych
}

\section{Wstęp}

Na rynku prasowym dostępne są periodyki przeznaczone wyłącznie dla brydżystów. Ich historia obejmuje już co najmniej kilkadziesiąt lat. Obecnie ukazują się dwa czasopisma: miesięczniki „Brydż” i „Świat Brydża”. Niniejszy tekst powstał na podstawie analizy obu tytułów, przy czym wzięto pod uwagę numery wydane w XX w., tj. do końca 2000 r. Oznacza to ponad 500 numerów w przypadku „Brydża” oraz ponad 100 w przypadku „Świata Brydża”. Podobny charakter obu pism pozwolił na uogólnienie wyników i wspólną prezentację.

Opisując edukacyjną funkcję czasopism brydżowych, niejednokrotnie posługiwałem się czasem teraźniejszym, co wymaga wyjaśnienia. Otóż pisząc o przeszłości, powinienem właściwie używać czasu przeszłego. Jednak, ponieważ oprócz badacza przeszłości jestem jednocześnie graczem i oba czasopisma są dla mnie dostępne na co dzień, toteż jestem przekonany, że omawiana przeze mnie edukacyjna funkcja jest pełniona nieprzerwanie do dziś w niezmienionej formie. Więc, by nie tworzyć niepotrzebnie klimatu minionych lat, pozwoliłem sobie używać czasu teraźniejszego.

Artykuł został skonstruowany następująco. Początek stanowi krótkie omówienie gry w brydża, co ma pozwolić niegrającym Czytelnikom lepiej zrozumieć dalsze treści. Jednocześnie mam świadomość tego, że terminologia stosowana w brydżu nie jest sprawą łatwą, dlatego, jeśli niniejszy tekst nie jest dostatecznie klarowny, zachęcam do korzystania z przypisów. W następnej części została krótko przedstawiona historia czasopism brydżowych, szczególnie miesięcznika

* Mgr, Zakład Andragogiki i Gerontologii Społecznej, Wydział Nauk o Wychowaniu, Uniwersytet Łódzki, 91-408 Łódź, ul. Pomorska 46/48. 
„Brydż”, będącego najstarszym pismem brydżowym w Polsce. Ostatecznie znalazło się omówienie kluczowych zagadnień, tzn. edukacyjnej funkcji rzeczonych czasopism, przy czym fragment ten został podzielony na punkty obejmujące jednostki tematyczne wyodrębnione w wyniku analizy.

\section{Brydż jako gra karciana}

Czytelnikom, którzy nie znają brydża, należy się kilka słów wprowadzenia, które pozwoli lepiej zrozumieć dalszy tekst. Brydż to gra karciana. Przy kwadratowym stoliku jednocześnie siedzą dwie pary usytuowane naprzemiennie. W zawodach wyższych rang używa się specjalnych zasłon dzielących stolik po przekątnej, oddzielających partnerów od siebie. W brydżu można wyróżnić dwie główne odmiany: tzw. brydż robrowy, nazywany także towarzyskim oraz brydż sportowy, w którym czynnik losowy ograniczony jest do minimum, a punktacja dostosowana jest do prowadzenia zawodów sportowych. Najmniejsza część rozgrywek brydżowych to jedno rozdanie ${ }^{1}$, w którym można wskazać dwie zasadnicze fazy: licytację i rozgrywkę. Obie mają doprowadzić do tego samego celu, czyli uzyskania jak najlepszego wyniku, jednak różnica pomiędzy nimi jest dość duża. Ponadto można zauważyć, że w wyniku licytacji jedna z par staje się parą atakującą, druga - broniącą. I tę ostatnią funkcję nazywa się wistem, stąd w fazie rozgrywki wyodrębnia się rozgrywającego i jego partnera (nazywanego dziadkiem) i parę wistującą ${ }^{2}$ Każda z tych części: licytacja, rozgrywka i wist wymaga specjalnych umiejętności, których rozwijaniem zajmują się publikacje brydżowe, w tym czasopisma.

Brydż sportowy pozwala na prowadzenie zawodów sportowych. Organizowane są turnieje na różnych szczeblach: od zawodów lokalnych do mistrzostw Polski i mistrzostw świata. W Polsce istnieje Polski Związek Brydża Sportowego, zrzeszający zawodników z całego kraju. Za osiągnięcia w zawodach przyznawane są tytuły klasyfikacyjne ${ }^{3}$.

Periodyki brydżowe dotyczą głównie brydża sportowego, ale błędem byłoby założenie, że są to pisma wyłącznie dla wyczynowych sportowców. Ich charakter jest bardzo uniwersalny - pozwala podnosić kwalifikacje brydżowe zarówno uznanym mistrzom, jak i adeptom gry oraz całkowitym amatorom.

${ }^{1} \mathrm{Na}$ zawodach sportowych przewiduje się czas na rozegranie jednego rozdania - około 7-8 min. Turniej brydżowy wymaga rozegrania kilkudziesięciu do kilkuset rozdań (te maksymalne liczby dotyczą zwykle dużych kilkudniowych imprez sportowych).

2 Rola dziadka jest bardzo ograniczona. Można zatem przyjąć, że o ile w fazie licytacji udział mają wszyscy czterej gracze, o tyle w fazie rozgrywki gra się toczy pomiędzy rozgrywającym a obrońcami, czyli wistującymi.

${ }^{3} \mathrm{Na}$ oficjalnej stronie internetowej Polskiego Związku Brydża Sportowego zamieszczony jest specjalny ranking, który uwzględnia punkty klasyfikacyjne wszystkich członków. Punkty klasyfikacyjne przyznawane są w wyniku zajęcia wysokich miejsc w organizowanych pod patronatem PZBS zawodów. Zebranie odpowiedniej liczby punktów owocuje przyznaniem stosownych tytułów. 


\section{Miesięcznik „Brydż”}

Miesięcznik „Brydż” jest najstarszym pismem o tej tematyce w Polsce. Pierwszy numer wydany w nakładzie 15 tys. egzemplarzy ukazał się w grudniu $1956 \mathrm{r}$. i zawierał 24 strony w formacie $200 \times 260$. Na pierwszej stronie redakcja zapowiedziała: „Przy ustalaniu koncepcji naszego miesięcznika zgodnie postanowiliśmy, że celem naszym będzie, aby jednocześnie uczył on, informował i bawił"4. Treści zostały podzielone na trzy główne działy. Pierwszy z nich - „Teoria” - obejmował wskazówki dla graczy dotyczące licytacji, nowoczesnych rozwiązań konwencyjnych, objaśnienia sygnałów wistowych, bezpiecznej rozgrywki oraz wielu innych zagadnień, które doczekały się teoretycznego opracowania. Drugi dział - „Problemy” - zawierał zadania do rozwiązania, co miało pomóc czytelnikom w szlifowaniu techniki brydżowej. Dział „Rozmaitości” natomiast obejmował sprawozdania z odbytych oraz zapowiedzi nadchodzących zawodów brydżowych, informacje o stosowanych przepisach, ciekawostki itp. W sierpniu 1958 r. wprowadzono nowy dział - „Trybuna Czytelników”, który zawierał listy do Redakcji, polemiki, relacje czytelników z rozegranych meczów itp. W 1960 r. zniesiono formalny podział na działy tematyczne, niemniej same treści do dziś wypełniają przytoczone wyżej zakresy, właściwie w niewiele zmienionej formule. W 1957 r. pojawił się pierwszy numer specjalny, wydany w nakładzie 6 tys. egzemplarzy.

Od końca lat 50. wielokrotnie zmieniała się okładka pisma, a w 1959 r. zmniejszono nieco format do rozmiaru $175 \times 250$, który przetrwał do lat 90 , a liczbę stron na wiele lat ustalono na 20. W 1962 r. do sześciu kolejnych numerów dodawano czterostronicowe wkładki formatu kieszonkowego pt. „Co każdy brydżysta wiedzieć powinien?”, zawierającą zbiór najpotrzebniejszych informacji dla każdego gracza. W 1964 r. pojawił się numer specjalny „Wist dla Wszystkich” zawierający aż 56 stron, a nakład wynosił aż 25 tysięcy egzemplarzy (2,5 razy więcej niż zwykły numer), co zapoczątkowało całą serię numerów specjalnych pod wspólnym tytułem „Brydż dla Wszystkich”, przypominających podręczniki do nauki gry. W 1973 r. objętość pisma zwiększono z 20 do 28 stron, a numer specjalny wydano w nakładzie 60 tys. egzemplarzy, co ustanowiło swoisty rekord miesięcznika.

W dwudziestolecie istnienia pisma, 12 grudnia 1976 r. zmarł współzałożyciel „Brydża”, jego redaktor naczelny - Aleksander Różecki, o którym koledzy z redakcji napisali: „Jako Naczelny Redaktor stworzył podstawy osiągnięcia wysokiego poziomu w tej dyscyplinie i sukcesów na arenie międzynarodowej. Należał również do szczupłego grona osób, które zapoczątkowały rozwój brydża sportowego i stworzyły ogólnopolską organizację. Był On najwybitniejszym brydżystą starszego pokolenia, wielokrotnym mistrzem Polski, reprezentantem Kraju, arcymistrzem obdarzonym zdolnością głębokiej analizy i dostrzegania problemów"5.

W lipcu 1977 r. wakat na stanowisku redaktora naczelnego objął Jerzy Pomianowski. W 1980 r. powrócono do objętości 20 stron pisma. Od 1985 r. na

4 „Brydż” [dalej: B] 1956, nr 1, s. 1.

5 Tamże, nr 12, s. 2. 
łamach miesięcznika wśród autorów zaczyna się pojawiać regularnie nazwisko Władysława Izdebskiego, który w przyszłości ma objąć stanowisko redaktora naczelnego „Świata Brydża" - pisma w pewnym sensie konkurencyjnego dla „Brydża”. W 1986 r. Jerzy Pomianowski proponuje wprowadzenie do słownika nowego terminu: „Istnieje ogromne zapotrzebowanie społeczne na nową naukę, które skromnie acz efektownie proponowałbym określić jako brydżologię stosowaną. Przedmiotem dociekań, badań i analiz w tej dziedzinie ludzkiego poznania powinno być wszystko, co w praktyce służy wygrywaniu w brydża"6. Co prawda, sam termin się nie przyjął, jednak ideologia tu nakreślona przyświecała autorom pisma przez wiele lat.

W 1991 r. wraz z przemianami w całym kraju nastąpiły zmiany w „Brydżu”. Zmieniono okładkę pisma, format zwiększono do rozmiaru A4, a liczba stron wzrosła do 34. Ale ważniejsze zmiany nastąpiły w sprawach własności. „Brydż” stał się własnością Spółki Wydawniczej, stworzonej przez grupę entuzjastów gry, w składzie: Marek Wójcicki, Jerzy Pomianowski, Grzegorz Matula, Stanisław Rumiński, Andrzej Zawada, Krzysztof Sokołowski, Jan Chodorowski i Jerzy Russyan. Jednocześnie pojawiły się pierwsze reklamy. Jednak pomimo bardziej komercyjnej oprawy idea pisma nie została zatracona. W styczniu 1993 r. redaktorem naczelnym został Sławomir Zawiślak, a wkrótce po nim Marian Szulc, który pełni tę funkcję do dziś.

\section{Inne czasopisma brydżowe ukazujące się w Polsce w XX w.}

Niewątpliwie miesięcznik „Brydż” ma najważniejsze miejsce wśród brydżowych publikacji periodycznych. Jest najstarszym pismem poświęconym tej tematyce, wydawanym bez przerwy od ponad pół wieku. Niemniej nie było to czasopismo jedyne. W 1956 r. w „Dzienniku Zachodnim - Wieczór”, a w 1957 r. w „Głosie Olsztyńskim” ukazywała się rubryka "Gramy w Brydża”. Ten sam redaktor odpowiadał za ukazującą się w latach 1956-1957 w „Kurierze Szczecińskim” rubrykę pt. „Bez Atu” oraz rubrykę pt. „Czwarty do Brydża”, z którą można się było zapoznać na łamach „Expressu Wieczornego” (1956-1958), a później w „Kulisach” (od 1957 r.). Także w „Głosie Szczecińskim” w 1957 r. pojawiła się rubryka „Przy Zielonym Stoliku” pod redakcją Edwarda Banasińskiego. W latach 1980-1986 ukazywało się nielegalne czasopismo „Pikier”, wydawane przez Łukasza Sławińskiego. W 1991 r. przez okres od maja do października we Wrocławiu wydawano „Bridge Forum” pod redakcją Cezarego Balickiego ${ }^{7}$.

Jednak najdłuższą karierą mógł i może się pochwalić - bo jest wydawany do dziś - miesięcznik „Świat Brydża”. Jest to pismo Polskiego Związku Brydża Sportowego, a jego pierwszym redaktorem naczelnym został Marian Szulc. Pierwszy numer ukazał się w sierpniu $1990 \mathrm{r}$.

\footnotetext{
6 B 1986, nr 5, s. 2.

7 Encyklopedia brydża, red. B. Seifert, Warszawa 1996.
} 
Przeglądając zawartość „Świata Brydża”, trudno nie zauważyć podobieństwa w formie i treści do miesięcznika „Brydż”. Relacje, problemy, zapowiedzi, polemiki, konkursy. Powtarzający się autorzy. Oczywiście istnieją pewne odmienności, jak np. „Szkółka Brydżowych Mistrzów”, czyli kącik poświęcony wyłącznie młodym adeptom brydża, w dużej mierze przez nich redagowany, jednak w ogólnym rozumieniu edukacyjnej funkcji czasopisma „Świat Brydża” nie jest pismem wyjątkowym. Obecnie wyróżnia go dużo doskonalsza szata graficzna, jednak w okresie, który został objęty niniejszą analizą (wszystkie numery do końca 2000 r.) łudząco przypominał „Brydża” - 40 stron formatu A5, czarny druk w kolorowej okładce.

\section{Edukacyjna funkcja czasopism brydżowych}

Edukacyjna funkcja czasopism jest czymś oczywistym. Poprzez popularyzowanie wiedzy o różnych zagadnieniach: ze świata polityki, gospodarki, sportu, mody itd. czasopisma stają się narzędziem edukacji, zwłaszcza w szerokim znaczeniu tego terminu. Niemniej idea czasopism brydżowych została zaprojektowana tak, by pełniły funkcję kształceniową w sposób szczególny. Co się na nią składa - zostało przedstawione poniżej. Warto tu zauważyć, że oba poddane analizie periodyki - „Brydż” i „Świat Brydża” pełnią wszystkie omawiane funkcje w podobnym stopniu i podobny sposób, dlatego wnioski zostały przedstawione łącznie.

\section{Problemy}

Jedną z największych atrakcji czasopism brydżowych jest rozwiązywanie problemów brydżowych. Właściwie nie można oprzeć się wrażeniu, że nawet artykuły poświęcone innym treściom, np. relacje z rozgrywek, aktualności, czy bardziej swobodne w formie teksty, takie jak felietony lub ciekawostki, muszą w małym przynajmniej stopniu zawierać jakieś problemy. Problem brydżowy to swego rodzaju zadanie do wykonania dla czytelnika; zwykle przedstawione jest podobnie jak np. końcówki szachowe - jako pewna sytuacja, która zaistniała lub mogła zaistnieć w trakcie gry, a istotą jej publikacji jest zadanie czytelnikowi pytania problemowego o to, jak należy postąpić, by osiągnąć zamierzony cel. Żeby uatrakcyjnić lekturę, prawidłowe rozwiązanie nie zawsze jest drukowane bezpośrednio po problemie, ale często na innej stronie lub nawet w kolejnym numerze. Daje to czytelnikowi czas na niezbędny namysł, usuwając jednocześnie pokusę w postaci gotowego rozwiązania będącego w zasięgu ręki.

Problemy miewają rozmaite tytuły, precyzujące ich charakter. Są to np. quizy, konkursy, testy, pojedynki itp. Tytuł może również od razu określać, jakich kompetencji brydżowych dotyczy, np.: Sprawdź, czy umiesz rozgrywać, W co zawistujesz?, Czytanie zakrytych rąk itp. Tytuł może również w inny sposób zachęcić do rozwiązywania problemów, np. Ucz się od Wohlina. Niemniej bez względu na 
rozmaitość tytułów i form całą tę grupę artykułów powszechnie nazywa się wspólną nazwą „problemy”, ponieważ najlepiej oddaje ona ich sens. Chodzi o nauczanie problemowe, czyli rozwiązywanie trudnych sytuacji, tu - sytuacji zaistniałych w brydżu.

Czego uczą problemy brydżowe? Zapewne przede wszystkim uczą lepiej grać. Owo kształtowanie umiejętności obejmuje wszystkie zakresy brydża: licytację ( $w$ ataku, w obronie), rozgrywkę, wist, ale także inne obszary, np. etykę gry. Każdy z tych zakresów można podzielić na kolejne mniejsze działy tematyczne, $\mathrm{np}$. konwencje licytacyjne, bezpieczna rozgrywka, rozgrywka w turnieju na maksy (na zapis maksymalny) ${ }^{8}$ itd. Jednocześnie należy zauważyć, że rozwiązywanie problemów brydżowych prowadzi nie tylko do szlifowania umiejętności samej gry. Otóż brydż pozwala rozwijać wiele innych kompetencji. Rozwiązywanie problemów prowadzi bowiem do rozwijania myślenia, przy czym w brydżu przede wszystkim rozwija się myślenie logiczne, kombinatoryczne, strategiczne. Ucząc się grać, można zrozumieć prawa rachunku zdań, rachunek prawdopodobieństwa czy mechanizmy postępowania w sytuacjach decyzyjnych.

Ponadto warto zwrócić uwagę na szczególną cechę brydża, której nie mają inne popularne gry towarzyskie, takie jak szachy, warcaby czy golf. Brydż to gra parami, a sukces w brydżu w znacznej mierze zależny jest od sprawnej komunikacji obu partnerów. Co więcej, sama nazwa brydż pochodzi z ang. bridge, co znaczy most, który stanowi symbol porozumienia. Stąd istotna część problematyki brydżowej dotyczy właściwej (owocnej i nietoksycznej) komunikacji zarówno na poziomie licytacji ${ }^{9}$, jak i rozgrywki ${ }^{10}$ (oczywiście w granicach przewidzianych przepisami gry).

Poprzez ukazywanie, analizę i dyskusję problemów czasopisma brydżowe podejmują się roli podobnej do podręczników lub materiałów szkoleniowych, których edukacyjna funkcja jest funkcją kluczową. Tym samym różnią się one jakościowo od innych periodyków sportowych, bowiem pozwalają nie tylko podziwiać zmagania mistrzów poprzez relacje z zawodów, lecz także dają szansę wcielić się czytelnikowi w rolę gracza, przed którym stoi konkretne wyzwanie.

\section{Aktualności}

W poddanych analizie czasopismach znaczną część objętości wypełniają treści, które zostały tu zatytułowane „Aktualnościami”. Należy to rozumieć jako informacje o bieżących wydarzeniach. Po pierwsze, są to relacje z imprez sporto-

${ }^{8}$ Zapis to sposób podliczania zdobytych punktów. Obecnie największą popularnością cieszą się dwa sposoby punktacji: IMP (Imternational Match Points) i maksy. Każdy z nich determinuje inny sposób postępowania podczas gry, tzn. wymaga podejmowania innych decyzji, co często jest przedmiotem analiz brydżystów.

${ }^{9}$ Szerzej na ten temat w podrozdziale Teoria.

${ }^{10} \mathrm{~W}$ fazie rozgrywki komunikacja dotyczy wyłącznie obrońców (wistujących). Ich zagrania mają na celu nie tylko osiągnięcie optymalnej $w$ danej chwili sytuacji, lecz także przekazywanie informacji partnerowi. Rozgrywający nie ma potrzeby komunikować się z partnerem (dziadkiem), dlatego jego wysiłki mogą stanowić co najwyżej próbę dezinformacji przeciwników, po to, by utrudnić im działania. 
wych na wysokich szczeblach: rozgrywek ligowych, mistrzostw kraju, ogólnopolskich kongresów, wreszcie imprez rangi międzynarodowej, takich jak mistrzostwa Europy czy świata. Sprawozdaniom tym towarzyszą oczywiście - podobnie jak w przypadku innych relacji sportowych - wyniki, tabele, punkty, klasyfikacje, składy drużyn itp. Można dowiedzieć się o szczegółowym przebiegu zawodów oraz o emocjach panujących podczas kluczowych zagrań. Jednak wydaje się, że wszystkie te dane stanowią jedynie pretekst do rozwiązywania problemów, przed którymi stanęli zawodnicy podczas omawianych rozgrywek. Właściwie nawet najdrobniejszym relacjom z mniejszych turniejów prawie zawsze towarzyszy opis przynajmniej jednego rozdania.

Aktualności to także zapowiedzi imprez brydżowych. Redaktorzy dbają, by ich czasopisma informowały ze stosownym wyprzedzeniem o zbliżających się turniejach, kongresach, mistrzostwach itp., a także o mniej oficjalnych rozgrywkach, jak np. wczasy brydżowe. Kalendarz imprez jest stale uaktualniany i uzupełniany o informacje od organizatorów o cenach, przewidywanych nagrodach, terminach, danych kontaktowych itp. Tym samym czasopisma brydżowe stanowią niejako forum łączące środowisko graczy.

Podsumowując, można zatem powiedzieć, że poprzez podawanie aktualnych wiadomości czasopisma brydżowe pełnią funkcję informacyjną, jednak w dużej mierze funkcja ta przeplata się z omawianą wyżej funkcją uczenia się problemowego.

\section{Teoria}

Łamy czasopism brydżowych stanowią miejsce publikacji teoretycznych podstaw gry. Nie mam ambicji, by w niniejszym artykule wyjaśnić, co składa się na ową teorię (czy też teorie). Chciałbym jedynie zaznaczyć, że brydż jest grą na tyle trudną, że zawsze dostarcza problemów, których rozwiązania nie są oczywiste nawet dla najznakomitszych graczy. Dlatego tworzone są teorie, które, obejmując pewne klasy problemów, stanowią podstawę ich rozwiązania. Na teorie te, najogólniej mówiąc, składają się w strefie licytacji tzw. konwencje, a w strefie rozgrywki i wistu tzw. prawa (choć nomenklatura nie jest tu zbyt precyzyjna i używa się również innych określeń). Konwencje brydżowe łączą się w większe układy teoretyczne, nazywane systemami licytacyjnymi ${ }^{11}$.

Teorie brydżowe są w pewnym sensie uogólnieniem tych samych treści, które składają się na problemy brydżowe. Wymagają nieco większej wiedzy brydżowej,

11 Celem licytacji jest zadeklarowanie przez jedną z par tzw. kontraktu, co znaczy (w dużym uproszczeniu) określenie liczby lew, które para zamierza zdobyć w fazie rozgrywki. By to osiągnąć, partnerzy muszą właściwie ocenić połączone siły. Mogą to robić wyłącznie za pomocą środków dozwolonych przepisami, czyli przy użyciu systemów licytacyjnych. System tworzy ustrukturalizowany zespół znaków, które służą przekazywaniu informacji. Systemy licytacyjne przypominają język, oczywiście ograniczony liczebnością znaków i zasobem treści. Podobnie jak języki, systemy licytacyjne można podzielić na naturalne i sztuczne, jednak nawet w naturalnych jest pewna doza "sztucznej” ingerencji w postaci umownych sekwencji. Dlatego nad znaczeniem poszczególnych odzywek (czyli pojedynczych znaków) pochylają się teoretycy brydża, chcąc w ten sposób udoskonalić sposób brydżowej komunikacji. 
zdolności spojrzenia z dystansu, często wypracowanej dzięki wieloletniej praktyce, niemniej do rozważań teoretycznych czasami wystarcza odrobina intuicji brydżowej, toteż można przyjąć, że to, co składa się na teorię brydża, nie jest wypracowywane wyłącznie przez najwybitniejszych tuzów, ale również przez „zwykłych" graczy.

Prezentacja teorii brydżowej może mieć po prostu postać przytoczenia gotowych rozwiązań, jednak często periodyki brydżowe wykorzystuje się do podjęcia polemiki wobec publikowanych treści.

\section{Udział czytelników w redagowaniu pism brydżowych}

Chęci współpracy z czytelnikami redaktorzy pism brydżowych dawali niejednokrotnie wyraz, jak choćby w tym apelu:

Piszcie do nas, przesyłajcie swe cenne uwagi, krytykujcie to, co się Wam w naszym piśmie nie podoba, wysuwajcie sugestie, co do spraw, które należałoby w nim poruszać. Wszystkie Wasze spostrzeżenia będziemy się starali uwzględnić w miarę naszych możliwości. Łamy nasze są otwarte dla każdego brydżysty w Polsce, który będzie miał coś ciekawego i nowego do powiedzenia w sprawach brydżowych, coś, co będzie mogło się przyczynić do rozwoju brydża sportowego ${ }^{12}$.

Te słowa znalazły swoje odbicie w sposobie redagowania pism. Czytelnicy nadsyłali listy, w których poruszali nurtujące ich tematy. Były to m.in. prośby o rozstrzygnięcie trudnych problemów, sugestie co do zawartości czasopisma, doniesienia „z terenu”, czyli z rozegranych rozdań, polemiki i dyskusje. Szczególną rolę pełnił comiesięczny konkurs, którego omówienie stanowiło swoiste forum dyskusyjne nt. licytacji.

Innymi słowy, formuła proponowana przez periodyki brydżowe zachęcała czytelników do aktywnego udziału w redakcji, przez co edukacyjna funkcja czasopisma ma charakter interaktywny, przekaz nie jest jednostronny, lecz dwu- lub wielostronny. Możliwość uzyskania odpowiedzi na swoje pytania, szansa dzielenia się spostrzeżeniami, czynny udział w omawianiu podjętych problemów - to wszystko dynamizuje przebieg działań we wszystkich innych obszarach.

\section{Rozmaitości}

Czasopisma brydżowe to także miejsce publikacji treści o lżejszym charakterze. W początkowych latach na łamach „Brydża” pojawiały się rysunki ubarwiające drukowane treści, później jednak z nich zrezygnowano. Powszechne jest zamieszczanie felietonów, które nie odbiegają znacząco od innych treści, za to mają bardziej swobodną formę, niejednokrotnie koloryzowaną dla uzyskania atrakcyjniejszego efektu. Ponadto w omawianych czasopismach można odnaleźć ciekawostki i drobne artykuły o humorystycznej tematyce. Pojawiały się niecodzienne zadania, jak np. „brydżówka” - szczególna odmiana krzyżówki oraz inne treści z pogranicza gry.

12 B 1956, nr 1, s. 1. 
Sądzę, że owe „rozmaitości” nadają czasopismom brydżowym bardziej przystępną formę, zwłaszcza dla czytelników, którzy nie traktują gry wyłącznie jako sportu nastawionego na podjęcie rywalizacji i osiąganie sportowych sukcesów, ale czasem nieco mniej serio - jako rozrywkę, czy hobby. Swobodny charakter niektórych treści przesuwa punkt ciężkości istoty czasopism ze sztywnego materiału szkoleniowego w stronę uniwersalnego narzędzia edukacyjnego - nie zapomina się o idei kształcenia przez zabawę; bądź co bądź, brydż jako gra może być traktowany przez niektórych czytelników wyłącznie w tej kategorii.

Termin „rozmaitości” traktuję odmiennie od zamierzeń autorów pierwszych numerów „Brydża”, w których w tym dziale pojawiały się przede wszystkim sprawozdania i zapowiedzi imprez sportowych. Pod tym pojęciem rozumiem zbiór wszystkich drobnych artykułów i notek, które nie znalazły się w innych działach. Jednocześnie chcę zauważyć, że zaproponowany podział jest w dużej mierze sztuczny. Jednoznaczne rozdzielenie tematyczne treści wydaje się niemożliwe i właściwie na co dzień niepotrzebne. Pomaga jedynie w przeprowadzeniu niniejszej analizy.

\section{Podsumowanie}

Omawiane przeze mnie miesięczniki „Brydż” i „Świat Brydża” mają w dużej mierze charakter edukacyjny. Co kryje się pod tym pojęciem, wyjaśniam dokładnie powyżej. Najistotniejsze wydaje się nauczanie problemowe, widoczne na niemal każdej stronie pism. Problemy brydżowe zachęcają w swojej formie do nauki gry w sposób wnikliwy, czynny, zaangażowany. Jednocześnie, ucząc brydża, rozwijają inne umiejętności, cenne także poza zielonym stolikiem.

Edukacyjną funkcję czasopism brydżowych określam poprzez złożone oddziaływanie na czytelnika za pomocą m.in. nauczania problemowego, informowania, rozważań teoretycznych, aktywnego włączania odbiorców w redagowanie pism oraz zabawę. Podkreślić jednakże należy, iż wyodrębnione działy - choć pozwalają lepiej zrozumieć sens edukacji - na łamach czasopism przeplatają się ze sobą, tworząc produkt atrakcyjny dla miłośników gry. 